\title{
Electronmicroscopy studies on the opsonic role of antiserum and the subsequent destruction of salmonellae within murine inflammatory leukocytes
}

\author{
YAN-NIE GUO, H. S. HSU*, V. R. MUMAW' and IRENE NAKONECZNA† \\ Departments of Microbiology and Immunology, and of + Pathology, Medical College of Virginia, Virginia \\ Commonwealth University, Richmond, VA 23298, USA
}

\begin{abstract}
Summary. Inbred female $\mathrm{C} 3 \mathrm{H}$ mice were given, by intraperitoneal injection, $4 \times 10^{7}$ virulent Salmonella typhimurium organisms opsonised with specific antiserum. Peritoneal washings were obtained between 1.5 and $24 \mathrm{~h}$ after injection and examined by electronmicroscopy. Opsonised salmonellae were ingested rapidly by peritoneal exudate cells and were digested rapidly. The presence of antibody facilitated the phagocytic efficiency of the host cells. Destruction of ingested bacteria appeared to be an innate capacity of the host phagocytes independent of the presence of antibody.
\end{abstract}

\section{Introduction}

Increasing experimental evidence shows the protective effect of inactivated (killed) vaccines against murine salmonellosis (Cronly-Dillon, 1972; Germanier, 1972; Herzberg et al., 1972; Marecki et al., 1975; Kuusi et al., 1979; Angerman and Eisenstein, 1980; Jorbeck et al., 1981; Svenson and Lindberg, 1981; Nakoneczna and Hsu, 1983). Nevertheless it is generally agreed that a live avirulent vaccine provides solid immunity against challenge because it induces both humoral and cellular immunity, whereas a killed vaccine induces only antibody production (Collins, 1974; Nakoneczna and Hsu, 1980 and 1983; Eisenstein and Sultzer, 1983; Hsu et al., 1985). It is believed that the mechanism of protection by killed vaccines is based on the opsonic action and cytophilic nature of antibodies (Wells and Hsu, 1970; Hsu and Mayo, 1973; Marecki et al., 1975; Jorbeck et al., 1981). Thus, antibodies facilitate the ingestion of, as well as attract the host phagocytes toward, the pathogen. The final elimination of the pathogen appears to depend on the ability of the host polymorphs and macrophages to destroy the ingested bacteria.

There is experimental evidence to show the destruction of virulent salmonellae within host phagocytes (Guo et al., 1986). Furthermore, macrophages from immunised animals do not have an enhanced capacity to kill salmonellae nor does the presence of humoral antibodies or lymphokines

Received 11 Jun. 1985, revised version accepted 17 Mar. 1986.

* Correspondence should be addressed to Dr H. S. Hsu. released by specific antigen-stimulated lymphocytes accelerate the rate of killing of salmonellae by macrophages (Hsu and Mayo, 1973; Marecki et al., 1975; Mayo et al., 1977). Many investigators still hold the traditional view that salmonellae are facultative intracellular parasites.

Guo et al. (1986) have presented electromicroscopic evidence of progressive degeneration of virulent Salmonella typhimurium within polymorphs and macrophages in the peritoneal exudate of infected mice. The present study extends that investigation to show the opsonic effect of antiserum and the subsequent rapid destruction of the ingested bacteria within host cells.

\section{Materials and methods}

\section{Organisms and growth}

A virulent strain of $S$. typhimurium, SR-11, was used. It was cultured in Tryptic Soy Broth (Difco) for $6 \mathrm{~h}$. The preparation of the bacterial suspensions in saline for intraperitoneal (ip) injection into mice was described by Hsu and Radcliffe (1968).

Mice

Three-month-old, inbred female $\mathrm{C} 3 \mathrm{H} / \mathrm{HeNMTV}$ mice were supplied by Litton Bionetics (Charleston, SC). They were found to be highly susceptible to challenge with $S$. typhimurium; the LD50 was $<10^{2}$ bacteria after ip inoculation.

\section{Antiserum}

Antiserum against $S$. typhimurium SR-11 was pre- 
pared in guinea pigs as previously described ( $\mathrm{Hsu}$ and Piper, 1972; Hsu and Mayo. 1973). Briefly, guinea pigs were given an intracutaneous injection of $10^{5}$ virulent $S$. typhimurium organisms and, after $2-4$ weeks, an ip injection of $10^{4}$ bacteria. They were bled by cardiac puncture 3-5 weeks later. Immune sera from 3-5 animals were pooled, checked for sterility and stored frozen until use. These antisera usually had an O-agglutination titre against $S$. 1yphimurium of $c .160$ (Marecki et al., 1975).

\section{Infection of mice with opsonised bacteria and collec-} tion of peritoneal exudates for electronmicroscopy.

A bacterial suspension containing $2 \times 10^{8}$ salmonellae/ $\mathrm{ml}$ was prepared in antiserum diluted 1 in 3 with saline. This mixture was incubated at $37 \mathrm{C}$ for $15 \mathrm{~min}$ and then vigorously dispersed in a Vortex $\mathrm{Jr}$ mixer. Eighteen mice were each given $4 \times 10^{7}$ salmonellae by ip injection in a $0 \cdot 2$ - $\mathrm{ml}$ volume. At intervals of $1 \cdot 5,3,6,9$ and $24 \mathrm{~h}$ after inoculation, three or four mice were killed with chloroform and their peritoneal washings were collected in Hanks's solution containing heparin 6 units $/ \mathrm{ml}$. The detailed procedure for preparing the peritoneal exudate cells (PEC) for electronmicroscopy was described by Guo et al. (1986).

\section{Results}

\section{Effect of bacterial infection}

Preliminary investigations revealed extensive phagocytosis of the injected opsonised salmonellae in the peritoneal cavities of the mice. Hence the sampling intervals for PEC were limited to the first $24 \mathrm{~h}$. Unpublished observations indicated that antiserum provided significant protection against infection at least by prolonging the survival time. The challenges of $4 \times 10^{7}$ salmonellae/mouse did not result in obvious symptoms of illness within the first $24 \mathrm{~h}$, although some mice appeared to be lethargic. When killed none of the mice showed gross evidence of abnormalities in the liver or spleen.

\section{Fate of opsonised salmonellae within the peritoneal} cavities of mice

Guo et al. (1986) described two sequences of events through which salmonellae degenerate within phagocytes. One is by a progressive cytoplasmic vacuolation followed by the disintegration of the bacterial envelope and the other by a diffuse condensation of cytoplasmic granules and compression of the bacterial envelope. The present findings were consistent with these observations.

At $1.5 \mathrm{~h}$ after infection. two salmonellae were seen in longitudinal section (solid arrows) just
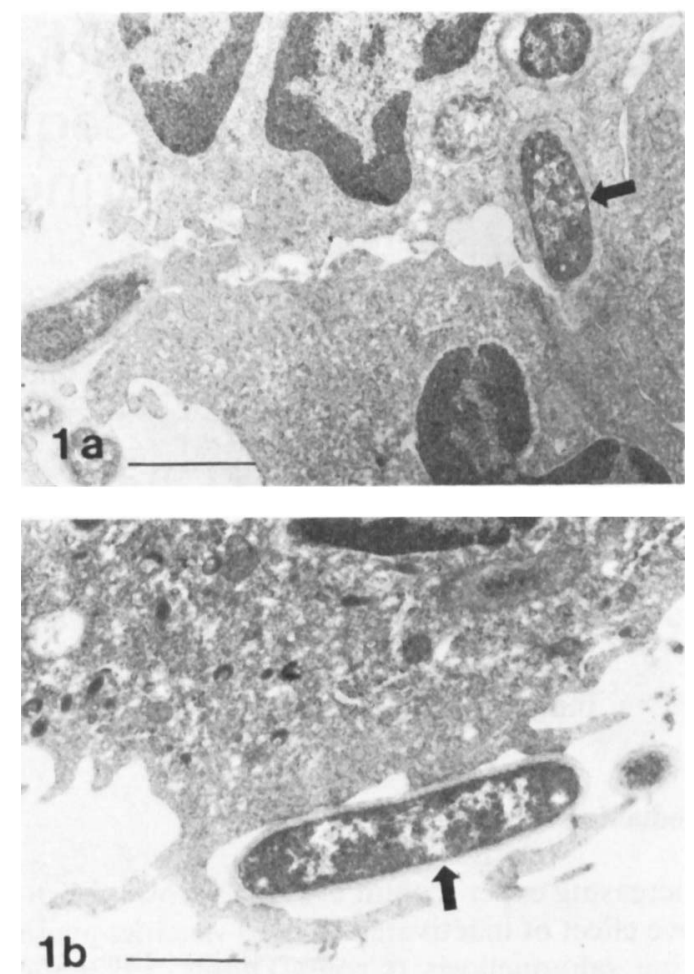

Fig. 1. ( $a$ and b) Salmonellae in the process of being phagocytosed, $1.5 \mathrm{~h}$ after injection $(\times 12750$; bar $=1.0 \mu \mathrm{m})$

about to be engulfed by leukocytes with their protruding pseudopodia (figs. la and $1 \mathrm{~b}$ ). They serve as a control for the cytological appearance of intact bacteria in the extracellular environment. Figs. 2 and 3 show two peritoneal polymorphs at $1.5 \mathrm{~h}$, each containing a large phagolysosome with $>20$ ingested bacteria at different stages of degeneration. Some of these bacteria display damage with cytoplasmic vacuolation (solid arrow); others show compression of bacterial envelope and diffuse condensation of cytoplasmic granules (arrow head). Fig. 4 shows that eosinophils were also engaged in antibacterial activities. In figs. 3 and 4, some intracellular bacteria appear to be in direct contact with the cytoplasm and without a clearly discernable phagosome membrane (V). Polymorphs at $3 \mathrm{~h}$ (fig. 5) contained bacteria at all stages of degeneration. The isolated organism at the bottom (solid arrow) appears to have been recently internalised while the others show cytoplasmic vacuolation and envelope disruption at different stages. The largest organism on the upper left (arrow head) appears to have been about to divide at the time of phagocytosis. Also at this time, several structures in the phagolysosomes (fig. 6a) could still be recognised as remnants of 

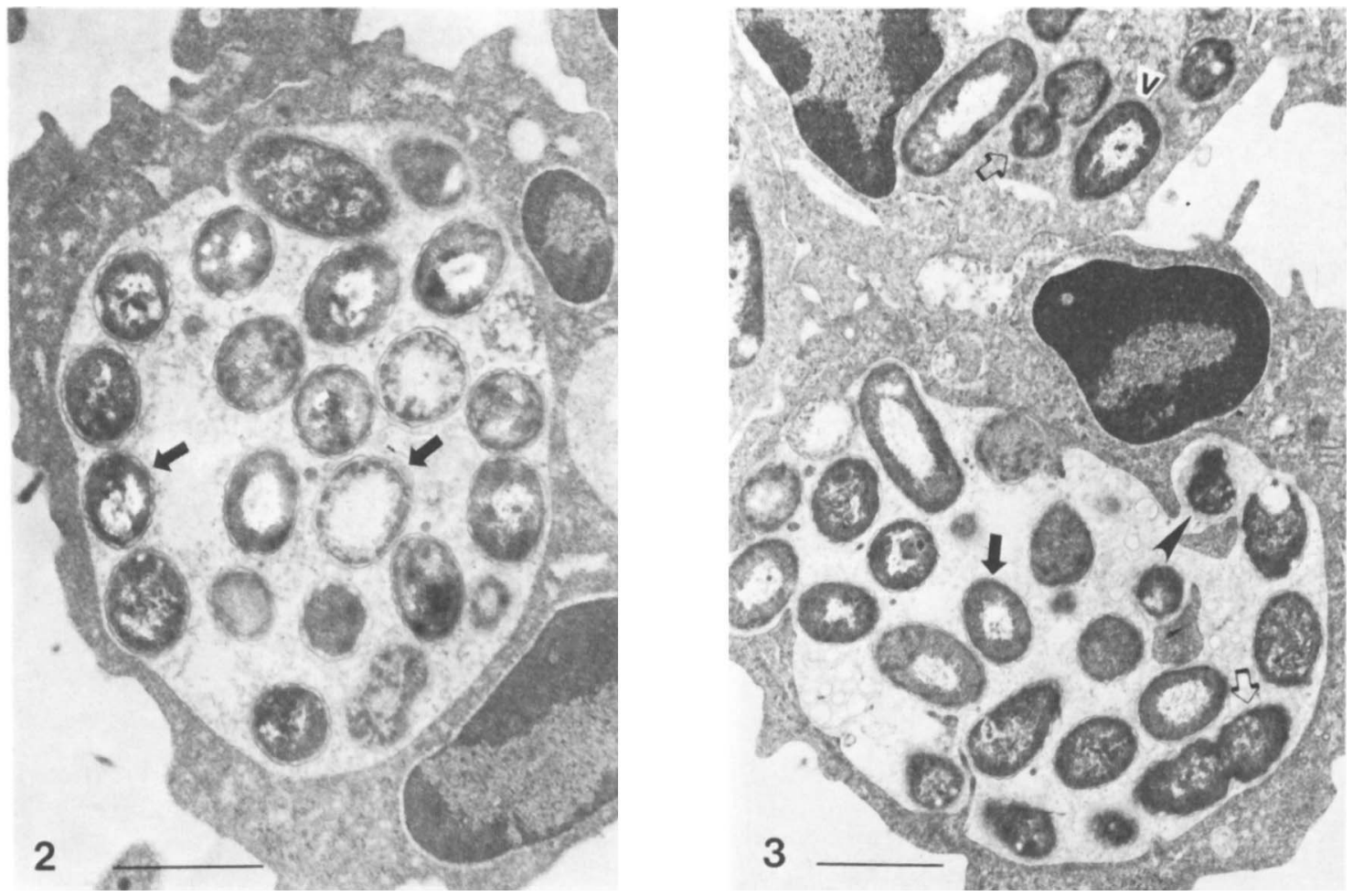

Fig. 2 and 3. Polymorphs containing ingested salmonellae $1.5 \mathrm{~h}$ after injection $(\times 16000$ and 12750 , respectively; bar $=1.0 \mu \mathrm{m})$.

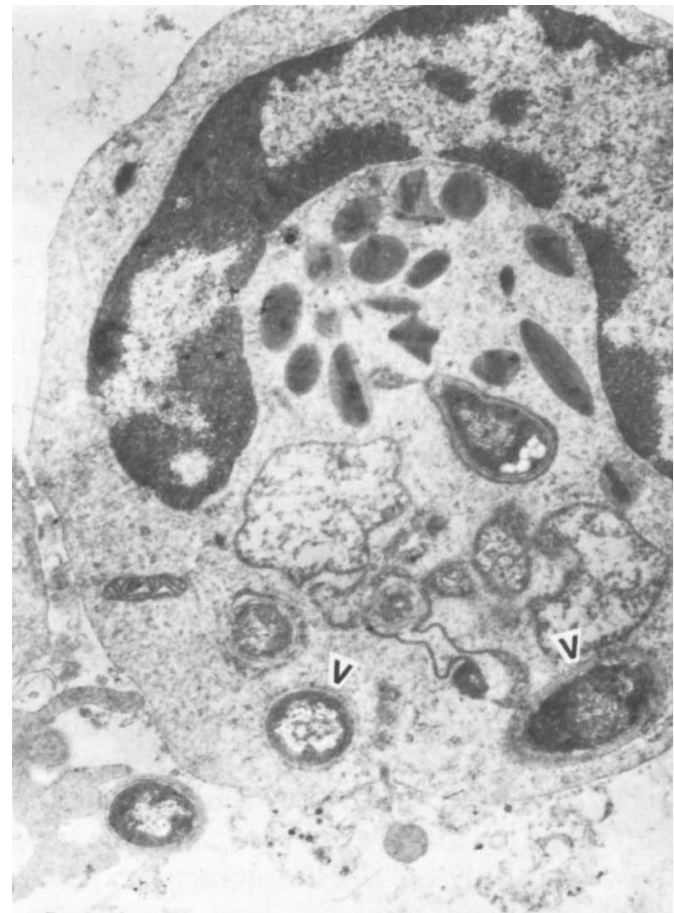

4

Fig. 4. An eosinophil with scattered, degenerating bacteria $1 \cdot 5 \mathrm{~h}$ after injection $(\times 12750$; bar $=1.0 \mu \mathrm{m})$.

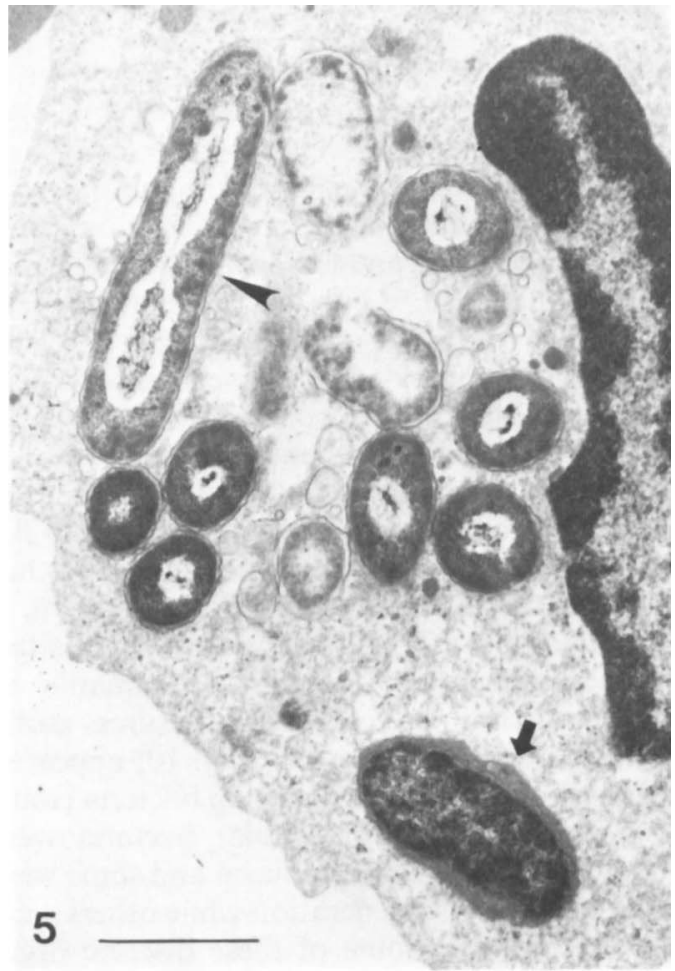

Fig. 5. A polymorph containing bacteria at various stages of disruption $3 \mathrm{~h}$ after injection $(\times 16000$; bar $=1.0 \mu \mathrm{m})$. 

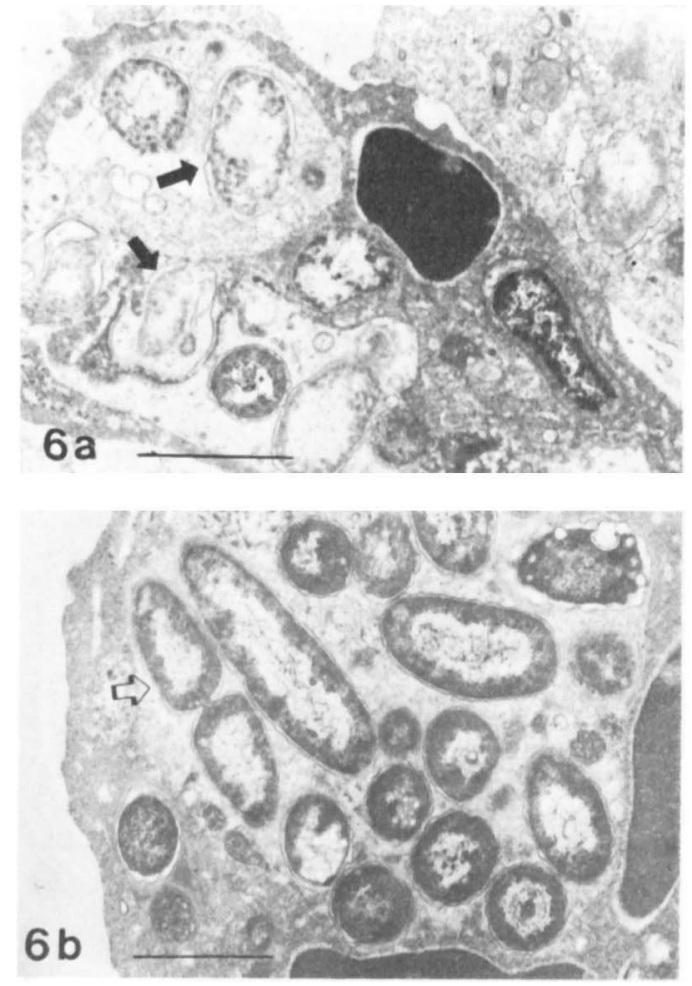

Fig. 6. ( $a$ and b) Polymorphs with ingested salmonellae at various stages of degeneration $3 \mathrm{~h}$ after injection $(\times 14000$ : bar $=$ $1 \cdot(1 \mu \mathrm{m})$

ingested organisms (solid arrow). Fig 6 b shows in greater detail the structure of bacterial envelopes undergoing degeneration. They appear curly and focally discontinuous instead of straight and continuous and are pulled away from the cytoplasmic contents. Thus, figs. 5 and 6 indicate destruction of virulent salmonellae in peritoneal exudate cells within $3 \mathrm{~h}$. By $6 \mathrm{~h}$ (figs. 7 and 8 ) extensive degradation of large numbers of opsonised bacteria had been accomplished in the polymorphs. Nevertheless, in spite of the large number of intracellular bacteria being digested, the host phagocytes generally appeared morphologically undamaged. In fig. 9. a macrophage after $9 \mathrm{~h}$ (nucleus marked $\mathrm{N}$ ) has just phagocytosed a polymorph which, in turn, is actively digesting a large number of salmonellae. This macrophage also contained remnants of digested bacterial or cellular structures (solid arrow). Macrophages after $24 \mathrm{~h}$ (fig. 10) appeared to have been ingesting and digesting bacteria continuously, because the intracellular bacteria were scattered throughout the cytoplasm and some were in an initial stage of degeneration while others were barely recognisable. Some of these discrete organisms appeared to be in direct contact with the cytoplasm and not enclosed in phagosomes (V).

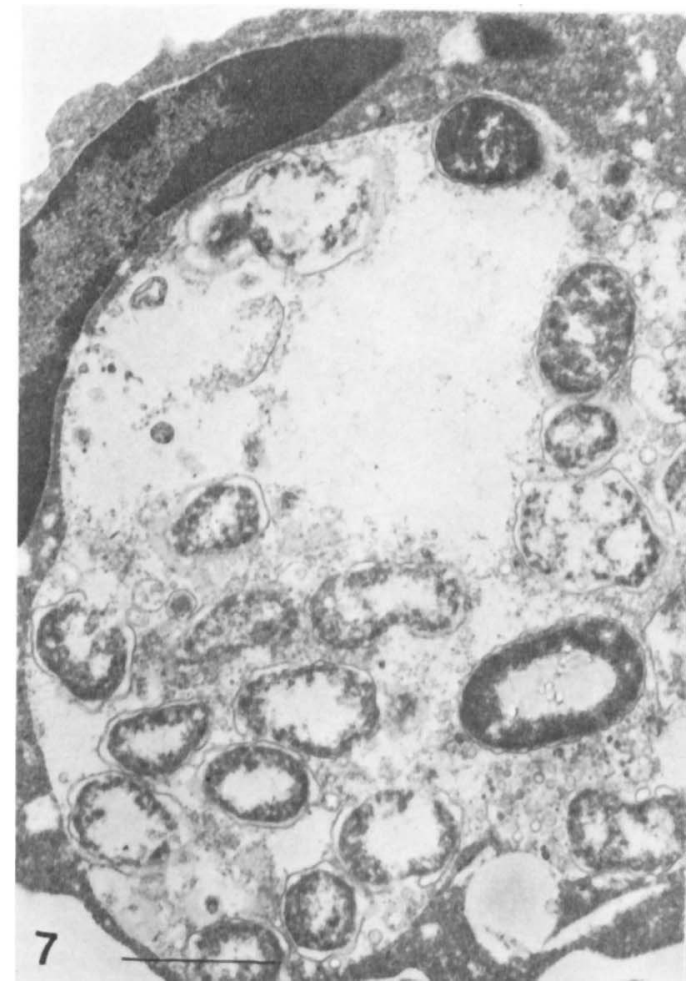

Fig. 7. A macrophage containing a large number of bacterial remnants $6 \mathrm{~h}$ after injection $(\times 16000 ; \mathrm{bar}=1 \cdot 0 \mu \mathrm{m})$.

\section{Discussion}

The primary function of antibody in protecting the host against many obligate extracellular bacteria is ascribed to its opsonic action. The classical example is seen in infection with Streptococcus pneumoniae, in which the opsonised pathogens are rapidly ingested and digested by host phagocytes. Convincing evidence shows that the protective effect of killed salmonella vaccines is achieved by their induction of opsonic and cytophilic antibodies in the host (Wells and Hsu, 1970; Hsu and Mayo, 1973; Marecki et al., 1975; Jorbeck et al., 1981). The thesis of an antibody-mediated immunity in murine salmonellosis therefore requires the demonstration of intracellular destruction of the opsonised pathogen. This paper describes enhanced phagocytosis and subsequent killing of virulent $S$. typhimurium within the peritoneal cavities of infected mice. However, the primary intention of this and the previous paper (Guo et al., 1986) was to study the direct interactions between invading pathogens and the host phagocytes in vivo. Thus it was desirable to inject a relatively large number $\left(10^{7}\right)$ of bacteria intraperitoneally to facilitate the observation of infected phagocytes by 

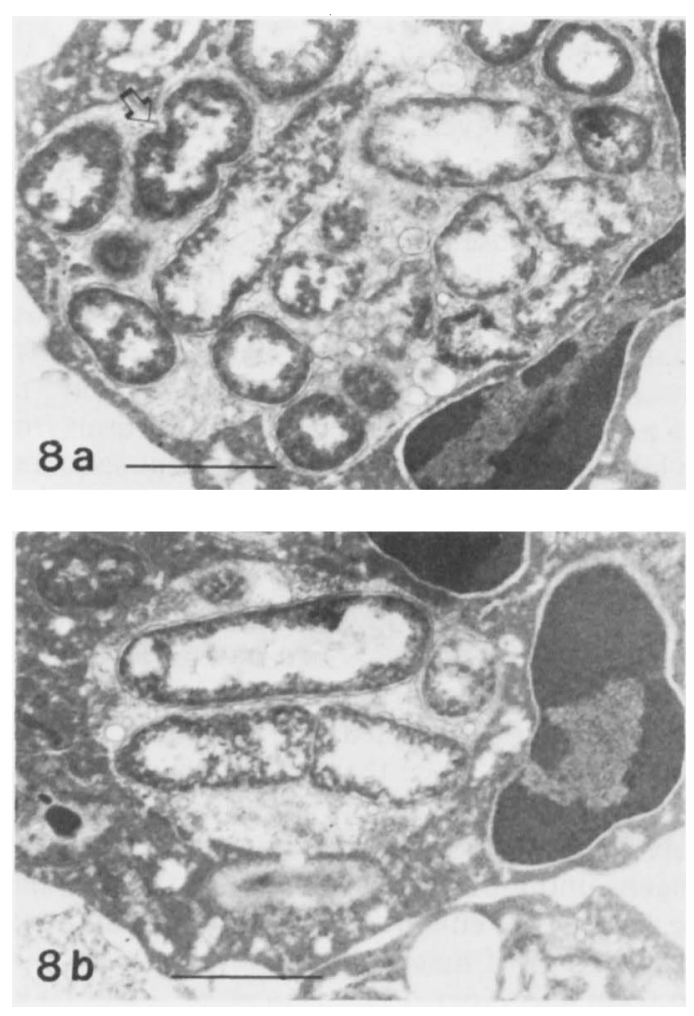

Fig. 8. (a and b) A macrophage and a polymorph, respectively, containing degraded bacteria $6 \mathrm{~h}$ after injection $(\times 14000$; bar $=$ $1.0 \mu \mathrm{m})$.

electronmicroscopy. Whether such an overwhelming challenge would be endotoxic or otherwise detrimental to the host was not at issue. On the other hand, regardless of the route of challenge (oral or intraperitoneal), once the infection is established in the tissues, the early host response involves acute inflammation with the initial infiltration predominantly of polymorphs (Nakoneczna and Hsu, 1980 and 1983). Hence, this experimental model adequately examines the early stage of the infectious process at a cellular level in murine salmonellosis.

The electronmicrographs reveal the sequence of events through which salmonellae were phagocytosed and destroyed by polymorphs and macrophages in the peritoneal exudate. The contrast in morphology between the intact extracellular (figs. $1 \mathrm{a}$ and $1 \mathrm{~b}$ ) and the degenerating intracellular bacteria (figs. 2 and 3) can be discerned and distinguished. Within $1.5 \mathrm{~h}$ after the injection of opsonised salmonellae into the peritoneal cavity, rapid acute inflammation ensued. Large numbers of the pathogen were being removed by many of the phagocytes and began to show obvious degradative changes (figs. 2 and 3 ). The fact that many bacteria were packed into one large phagolysosome

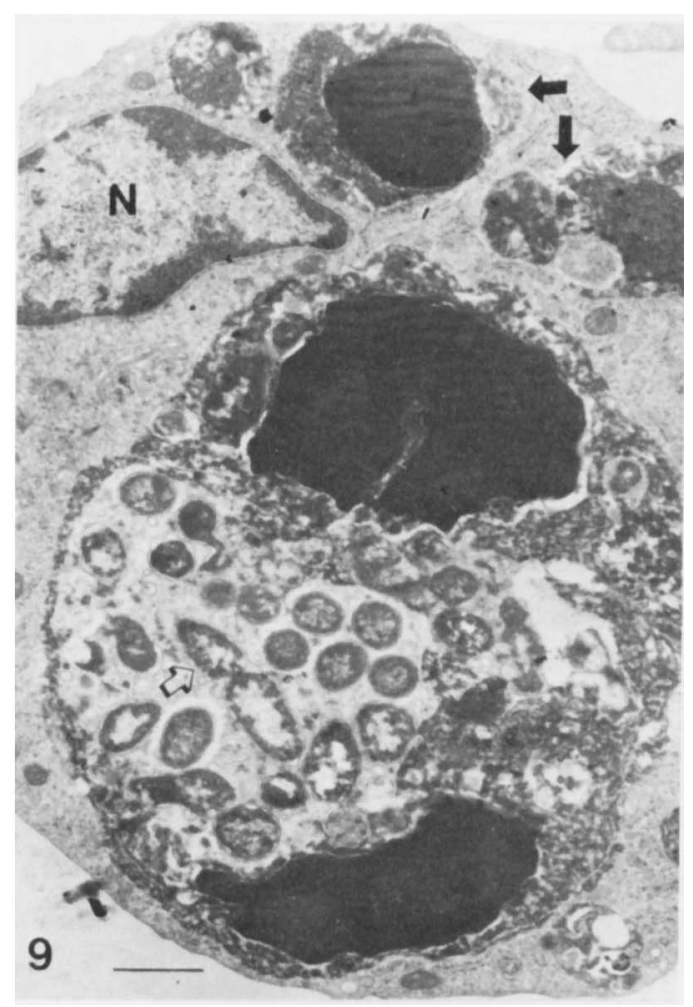

Fig. 9. A polymorph ingested by a macrophage $9 \mathrm{~h}$ after injection $(\times 9000$; bar $=1 \cdot 0 \mu \mathrm{m})$.

suggests their simultaneous ingestion and phagocytic efficiency in the presence of antiserum.

The intracellular destruction of virulent salmonellae proceeded rapidly once the organisms were internalised (Guo et al., 1986). This is best illustrated in fig. $6 \mathrm{a}$ where only ghosts of the ingested bacteria remained in the phagolysosomes of a polymorph at $3 \mathrm{~h}$. This suggests that the process, from ingestion to total degradation of virulent salmonellae, takes less than $3 \mathrm{~h}$ in the peritoneal cavity. However, the time required for an organism to disintegrate completely would vary amongst individual organisms, as seen in figs. 5 and $6 \mathrm{~b}$. The likelihood of a rapid ingestion of opsonised bacteria followed by their rapid destruction is also evident at $6 \mathrm{~h}$ (figs. 7, 8a and 8b). The peritoneal exudate cells arriving at the site of bacterial infection were actively fulfilling their phagocytic function against the pathogen in the presence of antiserum. The macrophages that arrived at the site of infection later were involved in ingesting bacteria (fig. 10) as well as other phagocytes (fig. 9).

This investigation also supports the contention that there is no evidence of survival or multiplication of virulent salmonellae within phagocytic leukocytes. On the contrary, electronmicrographs 


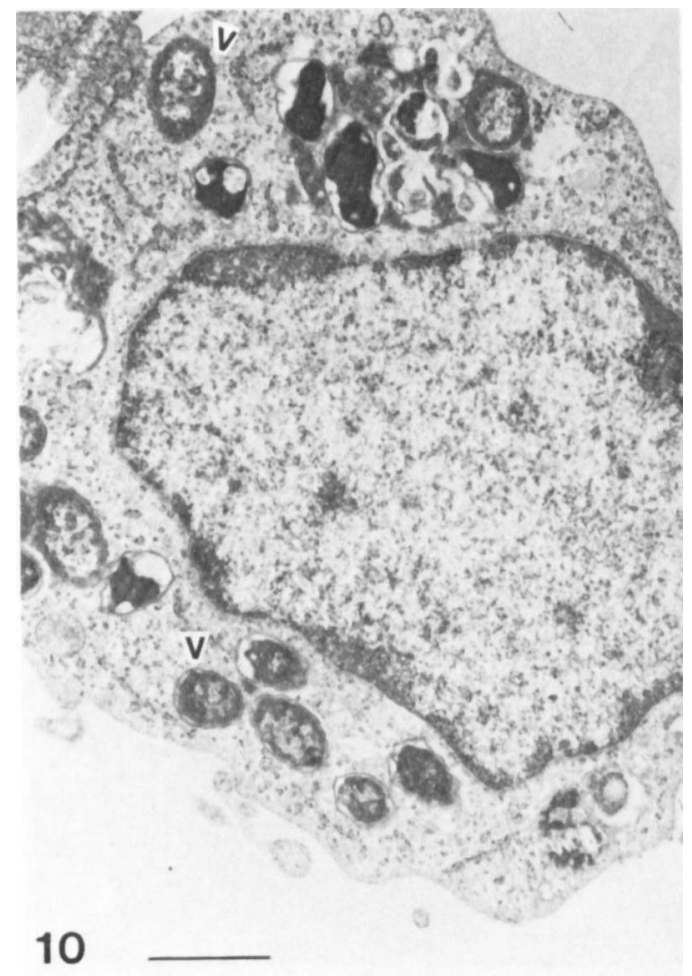

Fig. 10. A macrophage with ingested bacteria scattered throughout its cytoplasm $24 \mathrm{~h}$ after injection $(\times 11500$ : bar $=$ $1 \cdot(0 \mu \mathrm{m})$.

revealed degenerative changes in pairs of intracellular dividing bacteria which were probably ingested when they were undergoing division (hollow arrows in figs, $3,6 \mathrm{~b}, 8 \mathrm{a}$ and 9). Some of the individual intracellular bacteria did not appear to be bound within discernible phagosomes (figs. 4 and 10 ), but showed signs of degenerative changes. Similar phenomena of bacteria present in the "extraphagosomal cytoplasm" have been described with rickettsiae within polymorphs of guinea pigs (Rikihisa and Ito, 1982).

In comparison with the electronmicrographs published by Guo et al. (1986), it is clear that rapid intracellular destruction of virulent salmonellae

\section{REFERENCES}

Angerman C R. Eisenstein T K 1980 Correlation of the duration and magnitude of protection against Salmonella infection afforded by various vaccines with antibody titers. Infection and Immunity 27:435-443.

Cronly-Dillon S 1972 Comparative efficacy of whole and disintegrated killed vaccines against Salmonella typhimurium in mice. Journal of Medical Microbiolog. 5:183-189.

Collins F M 1974 Vaccines and cell-mediated immunity. Bacteriological Review's 38:371-402. occurs soon after their ingestion regardless of the presence or absence of antiserum in the tissue environment. However, the number of bacteria to be ingested as seen in the sections of these phagocytes is substantially increased in the presence of antiserum. Such observations provide definitive support for the thesis of an antibody-mediated immunity in salmonellosis and render the traditional contention of salmonellae as facultative intracellular bacteria untenable. Collectively, the data are consistent with previous publications from this laboratory which show that virulent salmonellae are more likely to be obligate extracellular bacteria and their pathogenicity is directly related to their antiphagocytic property (Wells and Hsu, 1970; Hsu and Piper, 1972; Hsu and Mayo, 1973; Marecki et al., 1975; Nakoneczna and Hsu, 1983). Acquired immunity in murine salmonellosis is primarily antibody-mediated and opsonic and cytophilic in nature. Once the pathogens are ingested, host phagocytes possess the innate capacity to inactivate them. Delayed hypersensitivity to bacterial antigens undoubtedly plays an important ancillary role, in part by enhanced inflammation and early accumulation of macrophages at the site of infection (Hsu and Piper, 1972; Hsu et al., 1980; Nakoneczna and Hsu, 1980; O'Brien et al., 1981). Therefore, killed vaccines can augment host resistance against challenges because of their induction of protective antibody (Nakoneczna and Hsu, 1983; Hsu et al., 1985).

This study was supported by the Grant-in-Aid Program for the Faculty of Virginia Commonwealth University and by U.S. Public Health Service grant AI 19434. Y-nG was a visiting scientist from the Department of Microbiology, Inner Mongolia Medical College, Huhehot, People's Republic of China. Her fellowship was funded by the Inner Mongolia Science and Technology Commission, PRC. Connie J. Wimbrough and Emily Graebner participated in the preliminary portion of this investigation under A. D. Williams Summer Fellowships, 1980 and 1981, respectively, School of Nursing, MCV/VCU. The authors wish to thank the staff of the Electron Microscope Laboratory of the Department of Pathology, R. H. Freeman, Ethel T. Lovings and T. D. Lutz, for their technical assistance.
Eisenstein T K, Sultzer B M 1983 Immunity to Salmonella infection. In: Eisenstein T K et al.(eds) Host defenses to intracellular pathogens. (Advances in Experimental Medicine and Biology 162) Plenum Publishing Corp., New York, pp 261 296.

Germanier R 1972 Immunity in experimental salmonellosis. III. Comparative immunization with viable and heat-inactivated cells of Salmonella typhimurium. Infection and Immunity 5:792-797.

Guo Y N, Hsu H S, Mumaw V R, Nakoneczna I 1986 Electronmicroscopy studies on the bactericidal action of inflamma- 
tory leukocytes in murine salmonellosis. Journal of Medical Microbiology 21:151-159.

Herzberg M, Nash P, Hino S 1972 Degree of immunity induced by killed vaccines to experimental salmonellosis in mice. Infection and Immunity 5:83-90.

Hsu H S, Mayo D R 1973 Interactions between macrophages of guinea pigs and salmonellae. III. Bactericidal action and cytophilic antibodies of macrophages of infected guinea pigs. Infection and Immunity 8:165-172.

Hsu H S, Miller K B, Nakoneczna I 1980 The role of delayed hypersensitivity in the enhancement of host resistance to infection. Canadian Journal of Microbiology 26:1438-1442.

Hsu H S, Nakoneczna I, Guo Y N 1985 Histopathological evidence for protective immunity induced by sonicated Salmonella vaccine. Canadian Journal of Microbiology 31:54-61.

Hsu H S, Piper V M 1972 Acquired resistance to and comparative virulence of Salmonella typhimurium demonstrated by cutaneous lesions in guinea pigs. Journal of the Reticuloendothelial Society 11:343-357.

Hsu H S, Radcliffe A S 1968 Interactions between macrophages of guinea pigs and salmonellae. I. Fate of Salmonella typhimurium within macrophages of normal guinea pigs. Journal of Bacteriology 96:191-197.

Jorbeck H J A, Svenson S B, Lindberg A A 1981 Artificial salmonella vaccines: Salmonella typhimurium $\mathrm{O}$-antigen-specific oligosaccharide-protein conjugates elicit opsonizing antibodies that enhance phagocytosis. Infection and Immunity 32:497-502.

Kuusi N, Nurminen M, Saxen $H$, Valtonen $\mathbf{M}$, Mäkelä P H 1979 Immunization with major outer membrane proteins in experimental salmonellosis of mice. Infection and Immunity 25:857-862.

Marecki N M, Hsu H S, Mayo D R 1975 Cellular and humoral aspects of host resistance in murine salmonellosis. British Journal of Experimental Pathology 56:231-243.

Mayo D R, Hsu H S, Lim F 1977 Interactions between salmonellae and macrophages of guinea pigs. IV. Relationship between migration inhibition and antibacterial action of macrophages. Infection and Immunity 18:52-59.

Nakoneczna I, Hsu H S 1980 The comparative histopathology of primary and secondary lesions in murine salmonellosis. British Journal of Experimental Pathology 61:76-84.

Nakoneczna I, Hsu H S 1983 Histopathological study of protective immunity against murine salmonellosis induced by killed vaccine. Infection and Immunity 39:423-430.

O'Brien A D, Scher I, Metcalf E S 1981 Genetically conferred defect in anti-salmonella antibody formation renders CBA $\mathrm{N}$ mice innately susceptible to Salmonella typhimurium infection. Journal of Immunology 126:1368-1372.

Rikihisa Y, Ito S 1982 Entry of Rickettsia tsutsugamushi into polymorphonuclear leukocytes. Infection and Immunity 38: 343-350.

Svenson S B, Lindberg A A 1981 Artificial salmonella vaccines: Salmonella typhimurium O-antigen-specific oligosaccharide-protein conjugates elicit protective antibodies in rabbits and mice. Infection and Immunity 32:490-496.

Wells P S, Hsu H S 1970 Interactions between macrophages of guinea pigs and salmonellae. II. Phagocytosis of Salmonella typhimurium by macrophages of normal guinea pigs. Infection and Immunity 2:145-149. 